\title{
Single Cell Protein Production Using Penicillium ochrochloron Chitinase and Its Evaluation in Fish Meal Formulations
}

Nilambari S Patil and Jyoti P Jadhav*

Department of Biotechnology, Shivaji University, Kolhapur, India

\begin{abstract}
The conversion of the enzymatic hydrolysate of shellfish chitin to single-cell protein was investigated. The endproduct of chitin hydrolysis by Penicillium ochrochloron chitinase was mainly N-acetyl-D-glucosamine, its further utilization as a substrate for SCP production using Yerrowia lipolytica NCIM 3450 has been studied. The 2\% chitin hydrolysate was found to be optimal for SCP production. A biomass of $9.4 \mathrm{~g} / \mathrm{l}$, total protein and nucleic acid content of the biomass was $65 \%$ and $2.9 \%$, respectively. Fish diets were formulated to replace fishmeal partially by single cell protein from Yerrowia lipolytica using chitin hydrolysate in diets of Lepidocephalus thermalis for a period of 2 weeks. Control diet and three experimental diets were prepared to replace $25 \%, 50 \%$ and $75 \%$ of fish meal using SCP. The result indicated $50 \%$ yeast SCP diet gave the better growth response in Lepidocephalus thermalis than other formulations.
\end{abstract}

Keywords: Lepidocephalus thermalis; Penicillium ochrochloron; Single cell protein; Yerrowia lipolytica

\section{Introduction}

Chitin, a poly- $\beta-1,4-\mathrm{N}$-acetylglucosamine, is an abundant renewable natural resource after cellulose. It constitutes as the structural polysaccharide of fungal cell walls and the outer shell of crustaceans, nematodes [1]. To date, the major source of industrial chitin comes from the wastes of marine food production, mainly crustacean shells, e.g. shrimp, crab or krill shells [2]. Crustacean shell waste consists mainly of $30-40 \%$ protein, $30-50 \%$ calcium carbonate, and $20-30 \%$ chitin [3].

In recent years, there has been a constant increase in the exploitation of fish resources and estimated quantity used for human consumption ( 105.6 million tons) is globally $75 \%$ of the worldwide fish production. The remaining $25 \%$ of the catch (34.8 million tons) are considered as wastes [4]. Seafood waste is one of the byproducts of shellfish processing industries. The industries are faced severe problems in disposing of the formidable quantity of chitinous shellfish solid wastes [5].

The conventional method of seafood processing includes chitin disposal by ocean dumping, incineration and land filling. However, factors such as cost of transportation and environmental pollution have prompted the search for alternative disposal methods. The chemical treatments also create waste disposal problems, because neutralization and detoxification of the discharged waste water are necessary $[5,6]$. Bioconversion is an effective way of reprocessing of waste material into useful value added products for the agricultural sector. The biotechnological potential of agro-industrial residues has been described earlier but there is hardly any such reference available on seafood processing wastes.

Aquaculture is a fast-growing industry, currently providing $>30 \%$ of the fish used for human consumption [7]. Aquafeeds is being used extensively in aquaculture as a major source of protein in formulated feeds. Because of rising prices and scarce availability, there is a need to replace fish meal partially or completely with single cell protein to bring down the cost of the fish feed. Considerable interest has focused on developing new fish feed in which the inclusion of fish meal is reduced by adding alternative sources of protein [7].The shellfish industries facing the waste disposal problem. Crab wastes have chitin concentrations of $13-15 \%$ [10]. Utilization of chitinous waste for single cell protein production and its use in aquaculture feed is a widely acceptable alternative $[8,9]$. It serves the dual purpose of solving the problems of environmental degradation arising from waste accumulation and providing a good protein source for fish diets.

Penicillium ochrochloron MTCC 517 is a potent producer of chitinolytic enzymes [10,11]. This paper concerns the enzymatic hydrolysis of chitin with $P$. ochrochloron culture filtrate and further utilization of the chitin hydrolysate for SCP production using Yerrowia lipolytica NCIM 3450. Also utilization of SCP in the diet of Lepidocephalus thermalis has been carried out.

\section{Materials and Methods}

\section{Microorganism and screening for SCP production}

Penicillium ochrochloron MTCC 517 was obtained from MTCC, Chandigarh, India. It was maintained on Potato Dextrose Agar (PDA) medium. Yerrowia lipolytica NCIM 3450, Yerrowia lipolytica NCIM 3472, Saccharomyces cerevisiae NCIM 3283, Saccharomyces cerevisiae NCIM 3284 yeast strains were used in this study, were procured from National Collection for Industrial Microorganisms (NCIM), Pune and maintained on YPD medium consisting of $1 \%$ yeast extract, $2 \%$ peptone, and $2 \%$ glucose.

\section{Single cell protein production}

Production was performed according to the method of Vyas and Deshpande [6].The Yerrowia lipolytica NCIM 3450 used for SCP was grown in a medium containing $(\mathrm{g} / \mathrm{l})$ : glucose, 10 ; yeast extract, 3.0 ; peptone, 5.0. After $24 \mathrm{~h}$ of incubation at $28^{\circ} \mathrm{C}$ under shaking conditions

${ }^{*}$ Corresponding author: Prof. Mrs. Jyoti P. Jadhav, Professor and Head Department of Biotechnology, Shivaji University, Vidyanagar, Kolhapur 416004 India, Tel: +912312609365; Fax: +912311691533; E-mail: jpjbiochem@gmail.com

Received July 19, 2014; Accepted September 04, 2014; Published September 11,2014

Citation: Patil NS, Jadhav JP (2014) Single Cell Protein Production Using Penicillium ochrochloron Chitinase and Its Evaluation in Fish Meal Formulations. J Microb Biochem Technol S4: 005. doi:10.4172/1948-5948.S4-005

Copyright: ( 2014 Patil NS, et al. This is an open-access article distributed under the terms of the Creative Commons Attribution License, which permits unrestricted use, distribution, and reproduction in any medium, provided the original author and source are credited 
Citation: Patil NS, Jadhav JP (2014) Single Cell Protein Production Using Penicillium ochrochloron Chitinase and Its Evaluation in Fish Meal Formulations. J Microb Biochem Technol S4: 005. doi:10.4172/1948-5948.S4-005

Page 2 of 4

(200 rpm), harvested cells were washed twice with distilled water. Using $2 \%$ acid swollen chitin as a substrate, hydrolysis was carried out at $40^{\circ} \mathrm{C}$ for $96 \mathrm{~h}$ on a rotator shaker as per the method of Patil et al. [10]. The chitin hydrolyzate obtained was supplemented with $0.67 \%$ yeast nitrogen base and inoculated with $2 \times 10^{8}$ cells of yeast. Yeast cells were calculated by using a Neubauer haemocytometer (Marienfeld). Cells harvested after $48 \mathrm{~h}$ of growth under shaking conditions at $30^{\circ} \mathrm{C}$ were studied for SCP parameters. The biomass yield, protein and nucleic acid content of Yerrowia lipolytica NCIM 3450 were determined by the methods described by Levine and Cooney [12].

\section{Experimental design}

Four rectangular glass tanks of about 5-litre capacity were used for the study. These were filled with water and covered with a chicken mesh. The tanks were all connected to aerators and the water was regularly aerated. Fishes (Lepidocephalus thermalis) were purchased from a local fish food supplier in Kolhapur city. They were stocked in the tanks at the rate of 8 fishes per tank and allowed to acclimate for a period of two weeks. During this period, dead fish were removed and the remaining fish were then redistributed at the rate of 5 fish per tank. During this period of acclimatization the fishes were trained to accept feed and fed with the control diet at $1.5 \%$ of their body weight twice daily at $10.00 \mathrm{~h}$ and $16.00 \mathrm{~h}$. Four food diets were formulated according to Al-Hafedh and Alam [13] and designated (A0, A1, A2, and A3) (Table 1). Water in all the tanks was changed on alternate day throughout the experiment. The fish was weighed in grams ( $\mathrm{g}$ ) on weighing balance and growth performance data was recorded.

\section{Proximate analysis of feed}

Analyses of dry matter (1100 C, $24 \mathrm{hrs),} \mathrm{Crude} \mathrm{protein} \mathrm{Kjeldahl}$ method (crude protein $=6.25 \times$ Kjeldahl nitrogen), crude fat (methanolchloroform extraction) in the diets were performed according to standard laboratory procedures [14].

\section{Determination of growth parameters}

Growth parameters were calculated from the initial and final weights; dry feed during the experiment using the following formulae:

1. Relative weight gain was calculated using following formula [15].

Relative weight gain $($ RWG $)=($ Final weight-Initial weight $) /$ Initial weight

2. Growth rate (g/fish/day)=(Final weight-Initial weight $) /$ experiment days

\begin{tabular}{|l|c|c|c|c|}
\hline Ingredients & $\mathbf{A}_{\mathbf{0}}$ & $\mathbf{A}_{\mathbf{1}}$ & $\mathbf{A}_{\mathbf{2}}$ & $\mathbf{A}_{\mathbf{3}}$ \\
\hline Fish meal & 34 & 25.5 & 17 & 8.5 \\
\hline Single cell protein & 0.00 & 11.6 & 23.2 & 34.8 \\
\hline Wheat bran & 25 & 28.9 & 31.8 & 32.7 \\
\hline Wheat flour & 9 & 9 & 9 & 9 \\
\hline Corn starch & 26.5 & 19.5 & 13.5 & 9.5 \\
\hline Cod liver oil & 1.5 & 1.5 & 1.5 & 1.5 \\
\hline Vitamins $^{1}$ & 2 & 2 & 2 & 2 \\
\hline Minerals $^{2}$ & 2 & 2 & 2 & 2 \\
\hline
\end{tabular}

Vitamin $\mathrm{mix}^{1}$ (g/kg mix): vit A (500000 IU/g), 1.5; 1.5; vit E (500 W/g), 6; vit K, 0.25 thiamin, 0.75 ; riboflavin, 1.5 ; pyridoxine, 0.75 ; nicotinic acid, 8.75 ; vit $\mathrm{C}$, 25; folic acid, 0.25 ; vit $B_{2}(1 \mathrm{~g} / \mathrm{kg}), 2.5$; inositol, 50 ; biotin (2\%), 6.25 ; calcium pantothenate, 2.5; choline (50\%). 200.

Mineral $\mathrm{mix}^{2}$ (g/kg mix): calcium carbonate, 215; magnesium hydroxide, $124 ; \mathrm{KCl}$, 90; fenic citrate, 20; $\mathrm{KI}, 0.4 ; \mathrm{NaCl}, 40$; Calcium Hydrogen Phosphate $\left(\mathrm{CaHPO}_{4}\right)$, 500; copper sulfate, 3 ; zinc sulfate, 4 ; cobalt sulfate, 0.2 ; manganese sulfate, 3 .

Table 1: Formulations of the experiment diets ( $\mathrm{g} / 100 \mathrm{~g}$ dry weight).

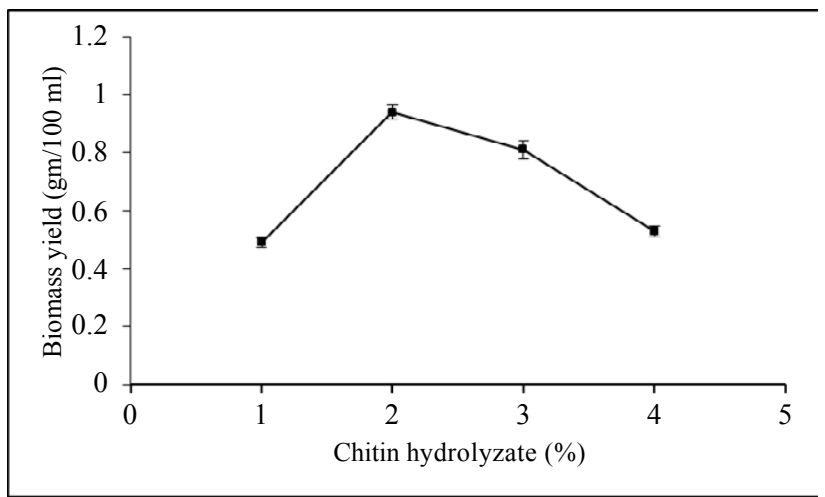

Figure 1: Effect of chitin hydrolysate on SCP production.

\section{Statistical analysis}

Data obtained were expressed as the mean \pm SD and analyzed statistically using (GraphPad InStat version 3.00, GraphPad Software, San Diego California, USA).

\section{Results and Discussion}

\section{Selection of yeast for Single Cell Protein (SCP) Production}

It was performed according to the method of Revah-Moiseev et al. [9]. Briefly, Yerrowia lipolytica NCIM 3450, Yerrowia lipolytica NCIM 3472, Saccharomyces cerevisiae NCIM 3283, Saccharomyces cerevisiae NCIM 3284 yeast strains were screened on solid medium containing chitin hydrolyzate with a yeast nitrogen source for rapid utilization of $\mathrm{N}$-acetylglucosamine. Among them, Yerrowia lipolytica NCIM 3450 was found to be the best one.

\section{Effect of chitin hydrolysate on SCP production}

Hydrolysis of chitin to $\mathrm{N}$-acetylglucosamine has been performed at $40^{\circ} \mathrm{C}$ for $96 \mathrm{~h}$ using Penicillium ochrochloron MTCC chitinase [10]. Figure 1 shows the biomass of Yerrowia lipolytica produced in the presence of chitin hydrolyzate obtained from enzymatic hydrolysis of colloidal chitin from chitinases of $P$. ochrochloron.

$\mathrm{N}$-acetylglucosamine could be easily metabolized by the $Y$. lipolytica thus giving higher biomass yield $(0.94 \mathrm{gm} / 100 \mathrm{ml})$. It was found that the biomass yield of yeast increased as the concentration of chitin hydrolysate increased in the medium. The $2 \%$ chitin hydrolysate was seen to be optimal for SCP production, as beyond which there was no increase in SCP production (Figure 1).

\section{Evaluation of parameters for single cell protein production}

Partial conversion of the raw material into yeast biomass (SCP) is useful because of the high nutritional quality of the yeasts. The advantages of microbial protein are high productivity, a high proportion of cell mass as protein, a good profile of desirable amino acids, good performance in feeding livestock and no toxic or carcinogenic compounds [16].

The criteria used for the evaluation of SCP production include growth yield, total protein and nucleic acid contents. Our results show that Yerrowia lipolytica is a better substitute than Pichia kudriavzevii and Saccharomyces cerevisiae NCIM 3052 as its protein content is higher ( $65 \%$ as compared to $61 \%$ and $45 \%$ respectively) and the nucleic acid content is lower $(2.9 \%$ as compared to $3.1 \%$ and $8-11 \%$ respectively), which are the criteria preferred for SCP [6]. Nucleic 
Citation: Patil NS, Jadhav JP (2014) Single Cell Protein Production Using Penicillium ochrochloron Chitinase and Its Evaluation in Fish Meal Formulations. J Microb Biochem Technol S4: 005. doi:10.4172/1948-5948.S4-005

Page 3 of 4

acids are very essential in the body; however Daramwal and Gaur [17] stated, foods with high nucleic acid content are unfit for human consumption. According to Protein Advisory Groups (PAG) of the United Nations, safe daily intake is estimated to be approximately $4 \mathrm{~g}$ of which $2 \mathrm{~g}$ can be derived from SCP [18].This indicates that quantities of protein and nucleic acid reported are acceptable values if consumed. Vyas and Deshpande [6] reported the production of SCP using chitin hydrolysate from the culture filtrate of Serratia marcescens. Revah et al. [9] have carried out saccharification of shell fish waste chitin and obtained SCP of Pichia kudriavzevii using the hydrolysate.

The sustainability of SCP for food industry is dependent on its composition since its nutritional value depends upon the pattern and concentration of essential amino acids [19]. The content of amino acids determines the proteins nutritive value. Y. lipolytica possesses the same general pattern of amino acids [20] as compared to the typical yeast [21]. The results of the study indicate that $P$. ochrochloron chitinase hydrolyzes chitin to NAG with high efficiency. Yerrowia lipolytica NCIM 3450 is appropriate yeast for bioconversion of chitin hydrolysate into single cell protein.

\section{Experimental fish and determination of growth parameters}

Lepidocephalus thermalis (Cobitis thermalis) is the one of the fish species produced in freshwater river system in India.

Table 2 describes nutrient analysis in control and experimental diets. The protein content of the diets was $32.83 \%$; fat content ranged from $5.34 \%$ to $6.12 \%$ and dry matter ranged from 96 to $97 \%$. Growth performance of fish is important parameter during feed trials. The growth parameters studied are listed in Table 3.

Out of the five diets tested, maximum growth of fish was observed in the A2 diet. It was clearly showed that test diet showed significantly better growth than control diet. The result of present work was supported by that of Mahnken et al. [22] who evaluated yeast as a substitute for fishmeal in Oregon Moist Pellet (OMP) for Oncorhynchus kisutch and Salmo gairdneri and observed that alkane yeast was an acceptable partial substitute for fishmeal in the rainbow trout diets. AlHafedh and Alam [13] reported that yeast SCP can replace up to $50 \%$ of fishmeal in juvenile Nile tilapia diets. Davies and Wareham [23] which showed that up to $40 \%$ fishmeal could be replaced by an industrial single cell protein without a significant reduction in growth.

In diets for Lepidocephalus thermalis, fishmeal could be replaced successfully with $50 \%$ yeast SCP. Fish feed technologists can use this protein source in fishmeal formulations. A major obstacle in the aquaculture industry is to ensure supply of high-quality fish feed. Aqua feeds have high protein content and this tends to increase the price of production, especially with the high inclusion level of fish meal.

\begin{tabular}{|l|c|c|c|c|}
\hline Parameters & $\mathbf{A}_{\mathbf{0}}$ & $\mathbf{A}_{\mathbf{1}}$ & $\mathbf{A}_{\mathbf{2}}$ & $\mathbf{A}_{\mathbf{3}}$ \\
\hline Dry matter & 96.83 & 97 & 97.21 & 97.34 \\
\hline Crude protein & 30.18 & 30.93 & 32.51 & 32.83 \\
\hline Fat & 5.34 & 5.45 & 6.08 & 6.12 \\
\hline
\end{tabular}

Table 2: Proximate chemical analysis of control and experimental diets.

\begin{tabular}{|l|c|c|c|c|}
\hline Parameters & $\mathbf{A}_{\mathbf{0}}$ & $\mathbf{A}_{\mathbf{1}}$ & $\mathbf{A}_{\mathbf{2}}$ & $\mathbf{A}_{\mathbf{3}}$ \\
\hline Initial weight & 0.53 & 0.63 & 0.56 & 0.59 \\
\hline Final weight & 0.71 & 0.91 & 1.48 & 1.51 \\
\hline Relative weight gain & 0.33 & 0.45 & 1.64 & 1.55 \\
\hline Growth rate (g/fish/day) & 0.012 & 0.018 & 0.061 & 0.06 \\
\hline
\end{tabular}

Table 3: Growth parameters of Lepidocephalus thermalis fed on diets with $0 \%$, $25 \%, 50 \%$, and $75 \%$ inclusions of single cell protein.
It has thus become imperative to search out for cheaper alternative protein sources to fish meal. Shellfish wastes generated from shellfish processing industries contains chitin as major component which accumulate in environment in considerable amount and creating pollution. Penicillium ochrochloron chitinase has ability to hydrolyse chitin into $\mathrm{N}$-acetyl-D-glucosamine. Its further utilization as a substrate for SCP production using yeast serves the dual role in reduction of environmental pollution and providing a good protein source for fish diets. Further studies are needed to find out effects of yeast SCP substitution fishmeal on other fish species.

\section{Acknowledgement}

Nilambari S. Patil wishes to thank UGC, New Delhi for awarding BSR meritorious fellowship for doctoral research. Corresponding author wishes to thank DBT-IPLS programme.

\section{References}

1. Wang S, Moyne A, Thottappilly G, Wu S, Locy RD, et al. (2001) Purification and characterization of a Bacillus cereus exochitinase. Enzyme Microb Technol 28: 492-498.

2. Xu Y, Gallert C, Winter J (2008) Chitin purification from shrimp wastes by microbial deproteination and decalcification. Appl Microbiol Biotechnol 79: 687697.

3. Kurita K (2006) Chitin and chitosan: functional biopolymers from marine crustaceans. Mar Biotechnol (NY) 8: 203-226.

4. FAO (2007) La situation mondiale des peches et de l'aquaculture. Departement des peches et de l'aquaculture, Rome.

5. Nirmala RR (1991) Shrimp waste utilization, INFOFISH Technical Handbook 4 Kulalumpur: INFOFISH.

6. Vyas PR, Deshpande MV (1991) Enzymatic hydrolysis of chitin by Myrothecium verrucaria chitinase complex and its utilization to produce SCP. J Gen Appl Microbiol 37:267-275.

7. Wulff T, Petersen J, Nørrelykke MR, Jessen F, Nielsen HH (2012) Proteome analysis of pyloric ceca: a methodology for fish feed development? J Agric Food Chem 60: 8457-8464.

8. Deshpande MV (1986) Enzymatic degradation of chitin and its biologica applications. J Sci Ind Res 45: 273-281.

9. Revah-Moiseev S, Carroad PA (1981) Conversion of the enzymatic hydrolysate of shellfish waste chitin to single-cell protein. Biotechnol Bioengg 23: 1067 1078.

10. Patil NS, Waghmare SR, Jadhav JP (2013) Purification and characterization of an extracellular antifungal chitinase from Penicillium ochrochloron MTCC 517 and its application in protoplast formation. Proc Biochem 48:176-183.

11. Patil NS, Jadhav JP (2014) Enzymatic production of N-acetyl-D-glucosamine by solid state fermentation of chitinase by Penicillium ochrochloron MTCC 517 using agricultural residues. Int Biodeter Biodegrad 91: 9-17.

12. Levine DW, Cooney CL (1973) Isolation and characterization of a thermotolerant methanol-utilizing yeast. Appl Microbiol 26: 982-990.

13. Al-hafedh Y, Alam A (2013) Replacement of fishmeal by single cell protein derived from yeast grown on date (Phoenix dactylifera) industry waste in the diet of Nile Tilapia (Oreochromis niloticus) fingerlings. J Appl Aquac 25: 346358

14. AOAC (Association of Official Analytical Chemists) (1984) Official methods of analysis (ed.) Association of official analytical chemists. Washington DC, pp.1141.

15. Utne F (1979) Standard Methods and Terminology in Finfish Nutrition. In proceedings of world symposium on finfish nutrition and fish feed technology, Hamburg, Berlin, pp. 438-443.

16. Rhishipal R, Philip R (1998) Selection of marine yeasts for the generation of single cell protein from prawn-shell waste. Bioresour Technol 65: 255-256.

17. Daramwal NS, Gaur R (2004) Single cell protein. In: Singh DP, Dwivedi SK (ed.) Environmental Microbiology and Biotechnology. New age international publishers, India, pp. 221-226. 
Citation: Patil NS, Jadhav JP (2014) Single Cell Protein Production Using Penicillium ochrochloron Chitinase and Its Evaluation in Fish Meal Formulations. J Microb Biochem Technol S4: 005. doi:10.4172/1948-5948.S4-005

18. Scrimshaw NS (1975) Single cell protein for human consumption-An overview. In: Tannenbaum SR, Wang DIC (ed.), Single cell protein II. Mass, MIT press, Cambridge, pp.158-178.

19. Henley EC, Kuster JM (1994) Protein quality evaluation by protein digestibilitycorrected amino acid scoring. Food Technol 48:74-77.

20. Pozo-Dengra J, Martinez-Rodriguez S, Martinez-Gomez Al, Las HerasVazquez FJ, Rodriguez-Vico F, et al. (2006) Screening of autolytic yeast strains for production of L-amino acids. Enzyme Microb Technol 40: 46-50.
21. Pyke RL, Brown ML (1975) Nutrition: An IntegratedApproach. 2nd ed, Wiley, New York.

22. Mahnken CVW, Spinelli J, Waknitz FW (1980) Evaluation of an alkane yeast (Candida sp) as a substitute for fishmeal as Oregon moist pellet: feeding trials with Rainbow trout (Oncorhynchus kisutch). Aquaculture 20: 41-56.

23. Davies SI, Wareham H (1988) A preliminary evaluation of an industrial single cell protein in practical diets for Tilapia Oreochromis mossambicus (Peters) Aquaculture 73: 189-199.
This article was originally published in a special issue, Chemical Engineering Science handled by Editor. Dr. Tingyue Gu, Ohio University, USA 